\title{
Growth and Yield of Fenugreek (Trigonella foenum-graecum L.) as Influenced By Different Levels of NPK under New Alluvial Plains of West Bengal, India
}

\author{
Nilanjana Datta ${ }^{1 *}$, J.K. Hore ${ }^{1}$ and Tapas Sarkar² \\ ${ }^{1}$ Department of Spices and Plantation Crops, Faculty of Horticulture, Bidhan Chandra Krishi \\ Viswavidyalaya (Agricultural University), Mohanpur-741252, Nadia, West Bengal, India \\ ${ }^{2}$ Department of Fruits and Orchard Management, Faculty of Horticulture, Bidhan Chandra Krishi \\ Viswavidyalaya (Agricultural University), Mohanpur-741252, Nadia, West Bengal, India \\ *Corresponding author
}

\section{A B S T R A C T}

\begin{tabular}{|l|}
\hline Ke y w or d s \\
Fenugreek, \\
Nitrogen, \\
Phosphorous, \\
Potassium. \\
\hline Article Info \\
\hline Accepted: \\
23 August 2017 \\
Available Online: \\
10 September 2017 \\
\hline
\end{tabular}

This investigation was undertaken to evaluate the performance of fenugreek under different levels of NPK for maximization of yield. The experiment was carried out at the HRS, Bidhan Chandra Krishi Viswavidyalaya, India during the year 2013-14 and 2014-15. The variety 'Hissar Sonali' was taken under the study. Three levels of each nitrogen (40, 60 and $80 \mathrm{~kg} / \mathrm{ha}$ ), phosphorus $(60,80$ and $100 \mathrm{~kg} / \mathrm{ha})$ and two levels of potassium (20 and $40 \mathrm{~kg} / \mathrm{ha}$ ) were included in this investigation. There were altogether 18 treatments. The experiment was laid out in Factorial Randomized Block Design (FRBD) with three replications. Among different treatment combination maximum plant height of $44.28 \mathrm{~cm}$ at 45 DAS with $\mathrm{N}_{80} \mathrm{P}_{80} \mathrm{~K}_{40}$ but at 105 DAS maximum plant height was observed with $\mathrm{N}_{60} \mathrm{P}_{100} \mathrm{~K}_{40}(108.17 \mathrm{~cm})$. Plants grown under $\mathrm{N}_{60} \mathrm{P}_{80} \mathrm{~K}_{40}$ combination, exhibited the maximum number of secondary branches (15.94) per plant. The yield attributing parameters like maximum pod length $(10.96 \mathrm{~cm})$ and number of seed per pod (15.32), maximum projected yield $(17.20 \mathrm{q} / \mathrm{ha})$ was recorded in $\mathrm{N}_{60} \mathrm{P}_{80} \mathrm{~K}_{40}$. From yield maximization point of view, the most effective treatment was NPK @ 60:80:40 kg/ha followed by NPK @ 40:80:40 kg/ha and NPK @ 60:100:40 kg/ha under alluvial plains of West Bengal.

\section{Introduction}

Fenugreek (Trigonella foenum-graecum L.), belonging to family leguminosae, as an important minor spice grown for its seed and leaves. It is commonly used as a condiments and seasoning in food preparation, is assumed to possess nutritive and restorative properties and has been need in folk medicine for centuries for a wide range of disease.it is well known traditional medicine for diabetes, indigestion, elevation of lipids and edema (fluid retention) on the legs. Fenugreek is also good source of dietary protein for human and animals. Seed of fenugreek are used locally as yellow die in cosmetics and medicinal purpose. The productivity of Fenugreek is controlled by many factors of which phosphorous nutrition and invidious use of irrigation are most important. Being a legume its nitrogen requirement is met from atmospheric nitrogen by rhizobium bacteria 
on its root nodules. The supply of phosphorous to legume is more important than nitrogen. Phosphorous is necessary for growth of Rhizobium bacteria, responsible for nitrogen fixation through nodulation. The reason for low productivity is either no uses or inadequate supply of nutrients.

However, the information on the nutritional requirements of this crop especially in the plains of west Bengal is meager. The present investigation was, therefore, carried out with a view to evaluate the efficacy of nitrogen, phosphorous and potassium and their interaction on growth and yield of fenugreek in the alluvial plains of West Bengal.

\section{Materials and Methods}

The was carried out at the Horticultural Research Station, Mondouri, Bidhan Chandra Krishi Viswavidyalaya, Mohanpur, Nadia, West Bengal during the year 2013-14 and 2014-15. The variety 'Hissar Sonali' was taken under the study. The soil at the experimental field was Gangetic alluvial with sandy clay loam texture, good water holding capacity, well drained with moderate soil fertility status and soil $\mathrm{pH}$ of 6.9. the organic carbon, total nitrogen, available phosphorous and potassium contents are $0.63 \%, 0.084 \%$, $18.07 \mathrm{~kg} \mathrm{ha}^{-1}$ and $194.80 \mathrm{~kg} \mathrm{ha}^{-1}$ respectively. The seeds were sown during $1^{\text {st }}$ week of November in $2.0 \mathrm{~m} \times 1.5 \mathrm{~m}$ plot at $30 \times 10 \mathrm{~cm}$ spacing during both the years. Standard package and practices were followed during the growing period of this crop.

Three levels of each nitrogen (40, 60 and 80 $\mathrm{kg} / \mathrm{ha}$ ), phosphorus $(60,80$ and $100 \mathrm{~kg} / \mathrm{ha})$ and two levels of potassium (20 and $40 \mathrm{~kg} / \mathrm{ha}$ ) were included in this investigation. The doses of fertilizer were adjusted with the application of urea, single super phosphate and muriate of potash. There were altogether 18 treatments. The experiment was laid out in Factorial Randomized Block Design (FRBD) with three replications. All experimental plots received a uniform dose of FYM at 15 tonnes/ha. FYM, $1 / 2$ dose of nitrogen, full dose of phosphorus and full dose of potash were applied as basal and the remaining $1 / 2$ dose of nitrogen was applied 30 days after sowing (DAS) as topdressing. Harvesting was done during end of March.

The observations were recorded on five randomly selected plants from each plot on different growth and yield parameters. The observations on plant height were recorded at 45 and 105 day after sowing. The projected yield per hectare was calculated on plot yield basis after deducting $25 \%$ area utilized for channel, ridges etc.

Data recorded on different parameters of fenugreek for both the years were pooled together and analyzed statistically through statistical software SPSS16.0 to express the result as there was difference between the two year in some treatments.

\section{Results and Discussion}

The height of the plants was recorded at 45 and 105 days after sowing (DAS) but number of secondary branches were recorded on 75 DAS.

\section{Plant height}

Data presented in tables 1 and 2, clearly indicated that plant height varied significantly in sole effect of three nutrients and in interactions at 45 days after sowing. As per sole effect of nitrogen, phosphorus and potassium, the plant height increased from $35.80-37.91 \mathrm{~cm}, 33.94-39.67 \mathrm{~cm}$ and $35.65-38.82 \mathrm{~cm}$ with increasing level of $\mathrm{N}_{40}$ to $\mathrm{N}_{80}, \mathrm{P}_{60}$ to $\mathrm{P}_{100}$ and $\mathrm{K}_{20}$ to $\mathrm{K}_{40}$ respectively. Among interactions $(\mathrm{N} \quad \mathrm{x} \quad \mathrm{P} \quad \mathrm{x} \quad \mathrm{K})$ the maximum plant height $(44.28 \mathrm{~cm})$ was observed in $\mathrm{N}_{80} \mathrm{P}_{80} \mathrm{~K}_{40}$ followed by $\mathrm{N}_{60} \mathrm{P}_{100} \mathrm{~K}_{40}$ $(44.15 \mathrm{~cm}), \quad \mathrm{N}_{40} \mathrm{P}_{100} \mathrm{~K}_{40} \quad(41.24 \quad \mathrm{~cm})$ as 
compared to minimum plant height under $\mathrm{N}_{80} \mathrm{P}_{80} \mathrm{~K}_{20}(31.15 \mathrm{~cm})$ combination.

The significant variations were noticed in both individual effect and in interaction effect. Increasing height with the increasing level of all three nutrients was also observed. The height increased from 88.55 to $96.06 \mathrm{~cm}$ with $\mathrm{N}_{40}$ to $\mathrm{N}_{80}$, from 86.51 to $97.27 \mathrm{~cm}$ with $\mathrm{P}_{60}$ to $\mathrm{P}_{100}$ and 88.91 to $96.75 \mathrm{~cm}$ with $\mathrm{K}_{20}$ to $\mathrm{K}_{40}$ respectively. As per interaction maximum plant height $(108.17 \mathrm{~cm})$ was recorded in $\mathrm{N}_{60} \mathrm{P}_{100} \mathrm{~K}_{40}$ followed by $\mathrm{N}_{80} \mathrm{P}_{80} \mathrm{~K}_{40}$ (103.17 $\mathrm{cm}), \mathrm{N}_{60} \mathrm{P}_{80} \mathrm{~K}_{40}(102.88 \mathrm{~cm})$ and $\mathrm{N}_{80} \mathrm{P}_{80} \mathrm{~K}_{20}$ $(101.36 \mathrm{~cm})$ but they were at par. The lowest plant height $(78.14 \mathrm{~cm})$ was found at $\mathrm{N}_{40} \mathrm{P}_{60} \mathrm{~K}_{20}$ combination (Tables 1 and 2).

Plant height increased with increasing nitrogen doses. A positive response to nitrogen application was also reported by (Tuncturk et al., 2011 and Mehta et al., 2012). This might be due to early and abundant availability of nitrogen leading to better nutritional environment in the root zone for growth and development of plant.

The findings of this investigation are in close conformity with those of (Halesh et al., 2000 and Mavai et al., 2000) who also recorded higher plant heights in fenugreek from higher phosphorus doses (75 and $90 \mathrm{~kg} \mathrm{P} / \mathrm{ha}$ respectively). In different studies related to phosphorus doses in fenugreek, (Jat, 2004) and reported that highest values in different parameters of fenugreek were obtained from $120 \mathrm{~kg} \mathrm{P} / \mathrm{ha}, 80 \mathrm{~kg} \mathrm{P} / \mathrm{ha}$ and $60 \mathrm{~kg} \mathrm{P} / \mathrm{ha}$ respectively. Phosphorus plays an important role in root development and proliferation as well as it also improves root nodule formation and biological $\mathrm{N}$ fixation by supplying assimilates to the roots.

\section{Number of secondary branches per plant}

In case of sole effect of nitrogen, the positive responses in number of secondary branches per plant were noticed with the increasing levels. The number of branches increased from 10.03 to 13.38 per plant with increase in nitrogen level from $40 \mathrm{~kg} / \mathrm{ha}$ to $80 \mathrm{~kg} / \mathrm{ha}$. In respect of phosphorus, the similar trend also noticed. The branch number increase from 11.09 to 13.16 with the increasing level of phosphorus from $60 \mathrm{~kg} / \mathrm{ha}$ to $100 \mathrm{~kg} / \mathrm{ha}$. In case of potassium increasing dose for 20 $\mathrm{kg} / \mathrm{ha}$ to $40 \mathrm{~kg} / \mathrm{ha}$ resulted in increasing branch number from 11.87 to 12.71. Among the interactions, the higher level of potassium with medium level of nitrogen and phosphorus generally produced more number of secondary branches per plant. The maximum number of branches was noticed with $\mathrm{N}_{60} \mathrm{P}_{80} \mathrm{~K}_{40}$ (15.94) followed by $\mathrm{N}_{80} \mathrm{P}_{100} \mathrm{~K}_{40}$ (15.16), $\mathrm{N}_{80} \mathrm{P}_{100} \mathrm{~K}_{20}$ (14.28) and $\mathrm{N}_{80} \mathrm{P}_{80} \mathrm{~K}_{40}$ (14.08) as compared to lowest number under $\mathrm{N}_{40} \mathrm{P}_{60} \mathrm{~K}_{20}$ (8.54) combination. The favourable effect of nitrogen and phosphorus on increasing the number of branches per plant have also been reported by (Pareek and Gupta, 1981 and Mehta et al., 2012).

\section{Length of pod}

The significant variations were recorded in case of both individual and interaction effect (Tables 3 and 4). Increase in the level of nitrogen $\left(\mathrm{N}_{40}-\mathrm{N}_{60}\right)$, phosphorus $\left(\mathrm{P}_{60}-\mathrm{P}_{80}\right)$ and potassium $\left(\mathrm{K}_{20}-\mathrm{K}_{40}\right)$ caused increase in length of pod from $8.61-9.45 \mathrm{~cm}, 8.43-$ $9.36 \mathrm{~cm}$ and $8.75-9.17 \mathrm{~cm}$ respectively. Further increase of level of nitrogen $\left(\mathrm{N}_{60}-\right.$ $\left.\mathrm{N}_{80}\right)$ and phosphorus $\left(\mathrm{P}_{80}-\mathrm{P}_{100}\right)$ after medium dose did not show any positive response. These results are similar to the findings of (Data et al., 2005) and (Thapa and Maity, 2004) who reported that pod length increased with nitrogen level upto $50 \mathrm{~kg} / \mathrm{ha}$. The favourable effect of phosphorus level on pod length also reported by (Khiriya and Singh 2003 and Bhunia et al., 2006). Khan et al., (2005) also recorded the increase in pod length from 9.27 to $11.42 \mathrm{~cm}$ with increasing 
level of phosphorus from $45 \mathrm{~kg} / \mathrm{ha}$ to 60 $\mathrm{kg} / \mathrm{ha}$. Among the interactions maximum pod length was noticed with $\mathrm{N}_{60} \mathrm{P}_{80} \mathrm{~K}_{40}(10.96 \mathrm{~cm})$ followed by $\mathrm{N}_{60} \mathrm{P}_{100} \mathrm{~K}_{40}(10.38 \mathrm{~cm})$ and $\mathrm{N}_{60} \mathrm{P}_{60} \mathrm{~K}_{40}(9.83 \mathrm{~cm})$ as compared to lowest pod length under $\mathrm{N}_{80} \mathrm{P}_{60} \mathrm{~K}_{20} \quad(8.15 \quad \mathrm{~cm})$ combination (Tables 3 and 4).

\section{Number of seed per pod}

In respect of number of seeds per pod the augmentation of nitrogen level from $\mathrm{N}_{40}$ to $\mathrm{N}_{60}$, phosphorus level from $\mathrm{P}_{60}$ to $\mathrm{P}_{100}$ and potassium level from $K_{20}$ to $K_{40}$ leads to increase in number of seed from 13.70 to $14.54,13.52$ to 14.53 and 13.88 to 14.51 .

The favourable effect of phosphorus on number of seed per pod also reported by several workers from different agroclimatic zone. Bhati, 1993; Khan et al., 2005; Tuncturk, 2011 and Datta and Verma, 2001, observed good response of phosphorus at 40 $\mathrm{kg} / \mathrm{ha}, 60 \mathrm{~kg} / \mathrm{ha}, 90 \mathrm{~kg} / \mathrm{ha}$ and $120 \mathrm{~kg} / \mathrm{ha}$ respectively on number of seeds per pod. Similar effect of nitrogen also reported by (Datta et al., 2005 and Tuncturk et al., 2011).

They observed the positive response of nitrogen upto $60 \mathrm{~kg} / \mathrm{ha}$. Among the interactions the medium level of nitrogen along with medium level of phosphorus and higher level of potassium recorded maximum seed per pod. The maximum seed per pod was observed in $\mathrm{N}_{60} \mathrm{P}_{80} \mathrm{~K}_{40}$ (15.32) followed by $\mathrm{N}_{60} \mathrm{P}_{100} \mathrm{~K}_{20} \quad$ (14.96), $\quad \mathrm{N}_{60} \mathrm{P}_{100} \mathrm{~K}_{40}$ (14.63) as compared to minimum seed per pod in treatment combination of $\mathrm{N}_{80} \mathrm{P}_{100} \mathrm{~K}_{20}$ (12.66).

Table.1 Individual effect of nitrogen, phosphorus and potassium on plant height (45 and 105 DAS) and number of secondary branches of fenugreek

\begin{tabular}{|c|c|c|c|c|c|c|c|c|c|}
\hline \multirow{2}{*}{ Treatments } & \multicolumn{3}{|c|}{$\begin{array}{c}\text { Plant height at } 45 \text { days } \\
\text { after sowing }\end{array}$} & \multicolumn{3}{|c|}{$\begin{array}{c}\text { Plant height at } 105 \text { days } \\
\text { after sowing }\end{array}$} & \multicolumn{3}{|c|}{$\begin{array}{l}\text { Number of secondary } \\
\text { branches per plant }\end{array}$} \\
\hline & 2013-14 & 2014-15 & Pooled & 2013-14 & 2014-15 & Pooled & 2013-14 & 2014-15 & Pooled \\
\hline \multicolumn{10}{|c|}{ Nitrogen (kg/ha) } \\
\hline $\mathrm{N}_{40}$ & 36.28 & 35.32 & 35.80 & 86.93 & 90.18 & 88.55 & 10.60 & 10.61 & 10.03 \\
\hline $\mathrm{N}_{60}$ & 36.29 & 37.34 & 36.82 & 93.21 & 94.56 & 93.88 & 12.76 & 13.18 & 12.97 \\
\hline $\mathrm{N}_{100}$ & 36.84 & 39.04 & 37.91 & 95.72 & 96.40 & 96.06 & 13.11 & 13.93 & 13.38 \\
\hline S. $\operatorname{Em}( \pm)$ & 0.406 & 0.368 & 0.257 & 0.197 & 0.366 & 0.150 & 0.128 & 0.143 & 0.098 \\
\hline CD (0.05) & NS & 1.060 & 0.742 & 0.568 & $\mathbf{1 . 0 5 3}$ & 0.433 & 0.370 & 0.411 & 0.282 \\
\hline \multicolumn{10}{|c|}{ Phosphorus (kg/ha) } \\
\hline $\mathrm{P}_{60}$ & 33.46 & 34.42 & 33.94 & 85.06 & 87.95 & 86.51 & 10.46 & 11.19 & 11.09 \\
\hline $\mathrm{P}_{80}$ & 35.95 & 37.65 & 36.80 & 92.27 & 97.16 & 94.72 & 12.74 & 12.96 & 12.85 \\
\hline $\mathrm{P}_{100}$ & 39.70 & 39.64 & 39.67 & 98.52 & 96.02 & 97.27 & 13.27 & 13.56 & 13.16 \\
\hline S. Em ( \pm$)$ & 0.406 & 0.368 & 0.257 & 0.197 & 0.366 & 0.150 & 0.128 & 0.143 & 0.098 \\
\hline CD (0.05) & 1.169 & 1.060 & 0.742 & 0.568 & 1.053 & 0.433 & 0.370 & 0.411 & 0.282 \\
\hline \multicolumn{10}{|c|}{ Potassium (kg/ha) } \\
\hline $\mathrm{K}_{20}$ & 33.59 & 35.65 & 35.65 & 88.50 & 89.31 & 88.91 & 11.50 & 11.78 & 11.87 \\
\hline $\mathrm{K}_{40}$ & 39.14 & 38.82 & 38.82 & 95.40 & 98.11 & 96.75 & 12.81 & 13.37 & 12.71 \\
\hline S. $\operatorname{Em}( \pm)$ & 0.331 & 0.637 & 0.210 & 0.161 & 0.299 & 0.123 & 0.105 & 0.116 & 0.080 \\
\hline CD (0.05) & 0.954 & 1.835 & 0.606 & 0.464 & $\mathbf{0 . 8 6 0}$ & 0.354 & 0.302 & 0.336 & 0.230 \\
\hline
\end{tabular}


Int.J.Curr.Microbiol.App.Sci (2017) 6(9): 2304-2312

Table.2 Interaction effect of nitrogen, phosphorus and potassium on plant height (45 and 105 DAS) and number of secondary branches of fenugreek

\begin{tabular}{|c|c|c|c|c|c|c|c|c|c|}
\hline \multirow[t]{2}{*}{ Treatments } & \multicolumn{3}{|c|}{$\begin{array}{l}\text { Plant height at } 45 \text { days after } \\
\text { sowing }\end{array}$} & \multicolumn{3}{|c|}{$\begin{array}{c}\text { Plant height at } 105 \text { days } \\
\text { after sowing }\end{array}$} & \multicolumn{3}{|c|}{$\begin{array}{c}\text { Number of secondary } \\
\text { branches per plant }\end{array}$} \\
\hline & 2013-14 & \begin{tabular}{|l|}
$2014-15$ \\
\end{tabular} & Pooled & 2013-14 & 2014-15 & Pooled & 2013-14 & 2014-15 & Pooled \\
\hline $\mathrm{N}_{40} \mathrm{P}_{60} \mathrm{~K}_{20}$ & 29.45 & 36.49 & 32.97 & 73.41 & 82.87 & 78.14 & 7.94 & 8.54 & 8.54 \\
\hline $\mathrm{N}_{40} \mathrm{P}_{80} \mathrm{~K}_{20}$ & 32.63 & 35.47 & 34.05 & 82.94 & 89.60 & 86.27 & 9.21 & 9.63 & 9.42 \\
\hline $\mathrm{N}_{40} \mathrm{P}_{100} \mathrm{~K}_{20}$ & 39.24 & 35.08 & 37.16 & 91.72 & 94.38 & 93.05 & 11.75 & 11.31 & 11.53 \\
\hline $\mathrm{N}_{60} \mathrm{P}_{60} \mathrm{~K}_{20}$ & 32.82 & 30.10 & 31.46 & 81.56 & 87.08 & 84.32 & 10.72 & 10.58 & 10.65 \\
\hline $\mathrm{N}_{60} \mathrm{P}_{80} \mathrm{~K}_{20}$ & 35.16 & 38.68 & 36.92 & 86.04 & 81.12 & 83.58 & 14.06 & 13.50 & 13.78 \\
\hline $\mathrm{N}_{60} \mathrm{P}_{100} \mathrm{~K}_{20}$ & 33.42 & 34.74 & 34.08 & 94.36 & 84.12 & 89.24 & 12.18 & 12.86 & 12.52 \\
\hline $\mathrm{N}_{80} \mathrm{P}_{60} \mathrm{~K}_{20}$ & 35.28 & 33.96 & 34.62 & 90.75 & 86.29 & 88.52 & 11.45 & 11.27 & 11.36 \\
\hline $\mathrm{N}_{80} \mathrm{P}_{80} \mathrm{~K}_{20}$ & 27.85 & 34.45 & 31.15 & 98.30 & 104.42 & 101.36 & 12.44 & 13.36 & 13.15 \\
\hline $\mathrm{N}_{80} \mathrm{P}_{100} \mathrm{~K}_{20}$ & 36.54 & 41.96 & 39.25 & 97.47 & 93.97 & 95.72 & 13.62 & 14.94 & 14.28 \\
\hline $\mathrm{N}_{40} \mathrm{P}_{60} \mathrm{~K}_{40}$ & 35.86 & 30.70 & 33.28 & 86.12 & 82.82 & 84.50 & 9.35 & 10.17 & 9.76 \\
\hline $\mathrm{N}_{40} \mathrm{P}_{80} \mathrm{~K}_{40}$ & 37.45 & 34.81 & 36.13 & 89.45 & 93.07 & 91.26 & 11.76 & 11.08 & 11.42 \\
\hline $\mathrm{N}_{40} \mathrm{P}_{100} \mathrm{~K}_{40}$ & 43.06 & 39.42 & 41.24 & 97.88 & 98.36 & 98.12 & 13.58 & 12.94 & 13.26 \\
\hline $\mathrm{N}_{60} \mathrm{P}_{60} \mathrm{~K}_{40}$ & 32.46 & 37.82 & 35.14 & 93.16 & 97.48 & 95.32 & 10.82 & 12.56 & 11.69 \\
\hline $\mathrm{N}_{60} \mathrm{P}_{80} \mathrm{~K}_{40}$ & 36.81 & 39.75 & 38.28 & 98.45 & 106.91 & 102.68 & 15.16 & 16.72 & 15.94 \\
\hline $\mathrm{N}_{60} \mathrm{P}_{100} \mathrm{~K}_{40}$ & 45.32 & 42.98 & 44.15 & 105.69 & 110.65 & 108.17 & 13.62 & 14.84 & 14.23 \\
\hline $\mathrm{N}_{80} \mathrm{P}_{60} \mathrm{~K}_{40}$ & 34.92 & 37.48 & 36.20 & 85.32 & 91.20 & 88.26 & 12.48 & 14.04 & 13.26 \\
\hline $\mathrm{N}_{80} \mathrm{P}_{80} \mathrm{~K}_{40}$ & 45.80 & 42.76 & 44.28 & 98.46 & 107.88 & 103.17 & 13.70 & 14.46 & 14.08 \\
\hline $\mathrm{N}_{80} \mathrm{P}_{100} \mathrm{~K}_{40}$ & 40.65 & 43.67 & 42.16 & 104.05 & 94.65 & 99.35 & 14.84 & 15.48 & 15.16 \\
\hline \multicolumn{10}{|l|}{ N X P } \\
\hline S. Em ( $( \pm)$ & 0.703 & 0.637 & 0.446 & 0.341 & 0.633 & 0.261 & 0.222 & 0.247 & 0.169 \\
\hline CD (0.05) & 2.025 & 1.835 & 1.285 & 0.984 & 1.824 & 0.751 & 0.641 & 0.712 & 0.488 \\
\hline \multicolumn{10}{|l|}{ PX K } \\
\hline S. Em ( $( \pm)$ & 0.574 & 0.520 & 0.364 & 0.279 & 0.517 & 0.213 & 0.182 & 0.202 & 0.138 \\
\hline CD (0.05) & N.S. & 1.499 & 1.049 & 0.803 & 1.489 & 0.613 & N.S. & 0.581 & N.S. \\
\hline \multicolumn{10}{|l|}{ N X K } \\
\hline S. Em $( \pm)$ & 0.574 & 0.520 & 0.364 & 0.279 & 0.517 & 0.213 & 0.182 & 0.202 & 0.138 \\
\hline CD (0.05) & 1.653 & 1.499 & 1.049 & 0.803 & 1.489 & 0.613 & 0.523 & N.S. & N.S. \\
\hline \multicolumn{10}{|l|}{ N X P X K } \\
\hline S. Em $( \pm)$ & 0.444 & 0.901 & 0.631 & 0.483 & 0.896 & 0.368 & 0.314 & 0.349 & 0.240 \\
\hline CD (0.05) & 2.863 & 2.596 & 1.817 & 1.391 & 2.580 & 1.062 & N.S. & N.S. & N.S. \\
\hline
\end{tabular}


Table.3 Individual effect of nitrogen, phosphorus and potassium on pod length,

Number of seed per pod and projected seed yield of fenugreek

\begin{tabular}{|c|c|c|c|c|c|c|c|c|c|}
\hline \multirow[b]{2}{*}{ Treatments } & \multicolumn{3}{|c|}{ Length of pod $(\mathrm{cm})$} & \multicolumn{3}{|c|}{ Number of Seed per pod } & \multicolumn{3}{|c|}{ Projected yield (q/ha) } \\
\hline & $\begin{array}{c}2013- \\
14\end{array}$ & $\begin{array}{c}2014- \\
15\end{array}$ & Pooled & $\begin{array}{c}\text { 2013- } \\
14\end{array}$ & 2014-15 & Pooled & 2013-14 & $\begin{array}{c}2014- \\
15\end{array}$ & $\begin{array}{c}\text { Poole } \\
\text { d }\end{array}$ \\
\hline \multicolumn{10}{|c|}{ Nitrogen $(\mathrm{kg} / \mathrm{ha})$} \\
\hline $\mathrm{N}_{40}$ & 8.61 & 8.6 & 8.61 & 13.64 & $4 \quad 13.77$ & 13.70 & 13.37 & 13.84 & 13.61 \\
\hline $\mathrm{N}_{60}$ & 9.48 & 9.42 & 8.45 & 14.42 & $2 \quad 14.64$ & 14.54 & 13.58 & 15.63 & 14.61 \\
\hline $\mathrm{N}_{100}$ & 8.65 & $8.9^{7}$ & 8.81 & 14.06 & $5 \quad 14.60$ & 14.32 & 11.85 & 13.59 & 12.72 \\
\hline S. Em $( \pm)$ & 0.075 & 0.05 & 0.62 & 0.092 & 20.106 & 0.073 & 0.122 & 0.143 & 0.098 \\
\hline CD (0.05) & 0.215 & 0.11 & 0.178 & 0.264 & $4 \quad 0.305$ & 0.210 & 0.350 & 0.412 & 0.283 \\
\hline \multicolumn{10}{|c|}{ Phosphorus (kg/ha) } \\
\hline $\mathrm{P}_{60}$ & 8.43 & 8.4 & 8.43 & 13.21 & 13.84 & 13.52 & 11.25 & 13.14 & 12.19 \\
\hline $\mathrm{P}_{80}$ & 9.23 & 9.4 & 9.36 & 14.36 & $5 \quad 14.62$ & 14.49 & 13.68 & 15.45 & 14.57 \\
\hline $\mathrm{P}_{100}$ & 9.08 & 9.08 & 9.08 & 14.55 & $5 \quad 14.57$ & 14.53 & 13.88 & 14.46 & 14.17 \\
\hline S. Em $( \pm)$ & 0.075 & 0.05 & 0.062 & 0.092 & 20.106 & 0.073 & 0.122 & 0.143 & 0.098 \\
\hline $\mathrm{CD}(\mathbf{0 . 0 5})$ & 0.215 & 0.16 & 0.178 & 0.264 & $4 \quad 0.305$ & 0.210 & 0.350 & 0.412 & 0.283 \\
\hline \multicolumn{10}{|c|}{ Potassium (kg/ha) } \\
\hline $\mathrm{K}_{20}$ & 8.64 & 8.8 & 8.75 & 13.81 & 13.94 & 13.88 & 12.32 & 13.44 & 12.88 \\
\hline $\mathrm{K}_{40}$ & 9.19 & 9.15 & 9.17 & 14.27 & 17.74 & 14.51 & 13.55 & 15.27 & 14.41 \\
\hline S. Em ( $( \pm)$ & 0.061 & 0.04 & 0.050 & 0.075 & 0.086 & 0.060 & 0.099 & 0.117 & 0.080 \\
\hline CD (0.05) & 0.175 & 0.13 & 0.145 & 0.214 & 0.249 & 0.172 & 0.284 & 0.336 & 0.231 \\
\hline
\end{tabular}


Table.4 Interaction effect of nitrogen, phosphorus and potassium on pod length, Number of seed per pod and projected seed yield of fenugreek

\begin{tabular}{|c|c|c|c|c|c|c|c|c|c|}
\hline \multirow{2}{*}{ Treatments } & \multicolumn{3}{|c|}{ Length of pod $(\mathrm{cm})$} & \multicolumn{3}{|c|}{ Number of Seed per pod } & \multicolumn{3}{|c|}{ Projected yield (q/ha) } \\
\hline & 2013-14 & 2014-15 & Pooled & 2013-14 & 2014-15 & Pooled & 2013-14 & 2014-15 & Pooled \\
\hline $\mathrm{N}_{40} \mathrm{P}_{60} \mathrm{~K}_{20}$ & 7.82 & 8.48 & 8.45 & 12.18 & 13.14 & 12.66 & 10.45 & 12.95 & 11.70 \\
\hline $\mathrm{N}_{40} \mathrm{P}_{80} \mathrm{~K}_{20}$ & 8.24 & 8.68 & 8.46 & 13.26 & 13.70 & 13.48 & 12.46 & 13.74 & 13.10 \\
\hline $\mathrm{N}_{40} \mathrm{P}_{100} \mathrm{~K}_{20}$ & 8.84 & 7.86 & 8.35 & 13.96 & 13.52 & 13.74 & 14.55 & 13.05 & 13.80 \\
\hline $\mathrm{N}_{60} \mathrm{P}_{60} \mathrm{~K}_{20}$ & 8.62 & 8.14 & 8.38 & 13.65 & 13.27 & 13.46 & 10.18 & 10.98 & 10.58 \\
\hline $\mathrm{N}_{60} \mathrm{P}_{80} \mathrm{~K}_{20}$ & 9.06 & 8.38 & 8.72 & 14.53 & 15.11 & 14.82 & 13.95 & 15.37 & 14.66 \\
\hline $\mathrm{N}_{60} \mathrm{P}_{100} \mathrm{~K}_{20}$ & 9.12 & 9.56 & 9.34 & 15.32 & 14.60 & 14.96 & 14.07 & 16.53 & 15.30 \\
\hline $\mathrm{N}_{80} \mathrm{P}_{60} \mathrm{~K}_{20}$ & 8.34 & 7.96 & 8.15 & 12.45 & 12.79 & 12.62 & 10.46 & 11.14 & 10.80 \\
\hline $\mathrm{N}_{80} \mathrm{P}_{80} \mathrm{~K}_{20}$ & 8.96 & 9.40 & 9.18 & 13.42 & 13.10 & 13.26 & 13.10 & 14.56 & 13.83 \\
\hline $\mathrm{N}_{80} \mathrm{P}_{100} \mathrm{~K}_{20}$ & 8.75 & 9.15 & 8.95 & 11.97 & 12.33 & 12.15 & 11.76 & 12.54 & 12.15 \\
\hline $\mathrm{N}_{40} \mathrm{P}_{60} \mathrm{~K}_{40}$ & 9.96 & 8.56 & 8.26 & 12.85 & 13.21 & 13.03 & 12.30 & 14.04 & 13.17 \\
\hline $\mathrm{N}_{40} \mathrm{P}_{80} \mathrm{~K}_{40}$ & 9.51 & 9.17 & 9.34 & 15.08 & 13.64 & 14.36 & 17.17 & 15.45 & 16.31 \\
\hline $\mathrm{N}_{40} \mathrm{P}_{100} \mathrm{~K}_{40}$ & 9.28 & 9.02 & 9.15 & 14.96 & 15.48 & 15.22 & 15.87 & 13.75 & 14.81 \\
\hline $\mathrm{N}_{60} \mathrm{P}_{60} \mathrm{~K}_{40}$ & 9.58 & 10.08 & 9.83 & 14.38 & 13.74 & 14.06 & 13.04 & 15.12 & 14.08 \\
\hline $\mathrm{N}_{60} \mathrm{P}_{80} \mathrm{~K}_{40}$ & 10.63 & 11.29 & 10.96 & 14.73 & 15.91 & 15.32 & 16.07 & 18.33 & 17.20 \\
\hline $\mathrm{N}_{60} \mathrm{P}_{100} \mathrm{~K}_{40}$ & 9.87 & 10.89 & 10.38 & 14.59 & 14.67 & 14.63 & 14.17 & 17.43 & 15.80 \\
\hline $\mathrm{N}_{80} \mathrm{P}_{60} \mathrm{~K}_{40}$ & 8.26 & 8.64 & 8.45 & 12.38 & 14.22 & 13.30 & 11.08 & 14.62 & 12.85 \\
\hline $\mathrm{N}_{80} \mathrm{P}_{80} \mathrm{~K}_{40}$ & 8.95 & 9.59 & 9.27 & 13.10 & 14.74 & 13.92 & 11.86 & 15.24 & 13.55 \\
\hline $\mathrm{N}_{80} \mathrm{P}_{100} \mathrm{~K}_{40}$ & 8.64 & 8.80 & 8.72 & 13.14 & 12.20 & 12.67 & 12.84 & 13.46 & 13.15 \\
\hline \multicolumn{10}{|l|}{$\mathbf{N X P}$} \\
\hline S. Em $( \pm)$ & 0.129 & 0.100 & 0.107 & 0.159 & 0.183 & 0.126 & 0.211 & 0.247 & 0.170 \\
\hline CD (0.05) & 0.372 & N.S. & N.S. & N.S. & 0.528 & 0.364 & 0.607 & 0.713 & 0.491 \\
\hline \multicolumn{10}{|l|}{ PX K } \\
\hline S. Em ( $( \pm)$ & 0.105 & 0.081 & 0.087 & 0.130 & 0.150 & 0.103 & 0.172 & 0.202 & 0.139 \\
\hline CD (0.05) & 0.304 & 0.234 & 0.252 & N.S. & N.S. & N.S. & 0.495 & N.S. & 0.401 \\
\hline \multicolumn{10}{|l|}{ N X K } \\
\hline S. Em $( \pm)$ & 0.105 & 0.081 & 0.087 & 0.130 & 0.150 & 0.103 & 0.172 & 0.202 & 0.139 \\
\hline CD (0.05) & 0.304 & 0.234 & 0.252 & 0.374 & N.S. & 0.297 & N.S. & 0.582 & 0.401 \\
\hline \multicolumn{10}{|l|}{ N X P X K } \\
\hline S. Em $( \pm)$ & 0.183 & 0.141 & 0.151 & 0.225 & 0.259 & 0.179 & 0.298 & 0.350 & 0.241 \\
\hline CD (0.05) & N.S. & 0.405 & 0.436 & 0.647 & 0.747 & 0.515 & N.S. & 1.008 & 0.694 \\
\hline
\end{tabular}




\section{Project yield per hectare}

In sole effect the maximum yield of 14.60 $\mathrm{q} / \mathrm{ha}$ was recorded with $\mathrm{N}$ at the rate of 60 $\mathrm{kg} / \mathrm{ha}$. In respect of phosphorus and potassium the maximum yield of $14.56 \mathrm{q} / \mathrm{ha}$ and 14.41 q/ha were observed with $80 \mathrm{~kg} \mathrm{P}$ and $40 \mathrm{~kg} \mathrm{~K}$ per hectare respectively. Among the interactions, the maximum projected yield was recorded with $\mathrm{N}_{60} \mathrm{P}_{80} \mathrm{~K}_{40}(17.20 \mathrm{q} / \mathrm{ha})$ followed by $\mathrm{N}_{40} \mathrm{P}_{80} \mathrm{~K}_{40} \quad(16.31 \mathrm{q} / \mathrm{ha})$ and $\mathrm{N}_{60} \mathrm{P}_{100} \mathrm{~K}_{40} \quad(15.80$ q/ha) as compared to lowest yield of $11.70 \mathrm{q} / \mathrm{ha}$ under $\mathrm{N}_{40} \mathrm{P}_{60} \mathrm{~K}_{20}$ combination.

The medium level of both nitrogen and phosphorus with higher level of potassium was more effective for maximization of yield. Both nitrogen and phosphorus applied beyond the lower dose delayed mainly because of better performance of growth parameters like plant height and number of branching which might have passed through long span resulted to delay in flowering (Data and Verma, 2001).

Application of phosphorus beyond $80 \mathrm{~kg} / \mathrm{ha}$ did not show any positive response in response in respect of yield and yield attributing character. This finding are also in good agreement with (Data and Verma, 2001) who did not get any positive response of application of phosphors beyond $120 \mathrm{~kg} / \mathrm{ha}$. The better yield and yield attributes with phosphorus fertilization might be due to its key role in root development, energy translocation and metabolic process of plant, through which increased translocation of photosynthate towards sink development might have occurred.

The maximum plant height $(108.17 \mathrm{~cm})$ was observed with medium level of nitrogen (60 $\mathrm{kg} / \mathrm{ha}$ ) with highest level of phosphorus (100 $\mathrm{kg} / \mathrm{ha}$ ) at 105 days after sowing. A positive response to phosphorus application may be due to favourable effect of phosphorus on nitrogen transformation leading to accumulation and metabolism of carbohydrates in plants (Baboo, 1997) reported higher ratio of phosphorus application increased height of the plant. Similarly, positive response of nitrogen, phosphorus and potassium upto $50 \mathrm{~kg} / \mathrm{ha}, 90$ $\mathrm{kg} / \mathrm{ha}$ and $60 \mathrm{~kg} / \mathrm{ha}$ were on number of branches per plant were reported by Thapa and Maity, 2004; Tuncturk, 2011 and Data and Verma, 2001 respectively.

The beneficial effect of $\mathrm{N}$ and $\mathrm{P}$ were perceptible in increased growth and profuse branching at early stages in the soils poor in these nutrients. The lack of significant yield differences at higher level of $\mathrm{N}$ application showed that Rhizobia associated with the roots of plant make up a part of its requirement. $\mathrm{N}$ and $\mathrm{P}$ applications had a beneficial effect on nodulation and this was reflected in higher seed yield (Detroja, 1996). Application of $60 \mathrm{~kg}$ and $80 \mathrm{~kg} \mathrm{~N} / \mathrm{ha}$ resulted in significantly higher plant height and number of branches per plant during both the years. This might be due to early and abundant availability of nitrogen leading to better nutritional environment in the root zone for growth and development of the crop as reported earlier (Pareek and Gupta, 1981 and Tuncturk et al., 2011).

From yield maximization point of view the most effective treatment was $\mathrm{N}_{60} \mathrm{P}_{80} \mathrm{~K}_{40}$ $(17.20 \mathrm{q} / \mathrm{ha})$ followed by $\mathrm{N}_{40} \mathrm{P}_{80} \mathrm{~K}_{40}$ (16.31 $\mathrm{q} / \mathrm{ha})$ and $\mathrm{N}_{60} \mathrm{P}_{100} \mathrm{~K}_{40}(15.80 \mathrm{q} / \mathrm{ha})$ under alluvial plains of West Bengal for fenugreek production.

\section{References}

Bhunia, S.R., Chauhan, R.P.S, Yadav, B.S. and Bhati, A.S. 2006. Effect of phosphorus, irrigation and Rhizobium on productivity, water use and nutrient uptake in fenugreek (Trigonella 
foenum-graecum). Indian J. Agron.51 (3): 239-41.

Data, R., and Verma, J.P. 2001. Effect of level of phosphorus and potash on the performance of seed crop of fenugreek (Trigonell afoenum-graecum) cv. Pusa Early Bunching.Haryana J. Hort. Sci. 30(3/4): 249-50.

Detroja, H.J., Sukhadia, N.M., Khanpara, V.D., Malavia, D.D. and Kaneria, B.B. 1996. Response of fenugreek (Trigonellafoenum-graecum) to nitrogen, phosphorus and potassium.Indian J. Agron.41 (1):17980.

Halesh, D.P., Gowda, M.C., Forooqi, A.A., Vasundhara, M. and Srinivasappa, K.N. 2000. Influence of nitrogen and phosphorus on growth, yield and nutrient content of fenugreek (Trigonella foenum-graecum L.). Contributory Papers Centennial Conference on Spices and Aromatic Pants, Calicut, Kerala, India, 20-23 September, pp-191-94.

Jat, B.I., 2004. Effect of phosphorous, sulphur and biofertilizer on yield attrbutes and yield of fenugreek (Trigonellafoenumgraecum L.). Legume Res. 27(1): 37 41.

Khiriya, K.D., and Singh, B.P. 2003. Effect of phosphorus and farmyard manure on yield, yield attributes and nitrogen, phosphorus and potassium uptake of fenugreek (Trigonella foenumgraecum). Indian J. Agron.48 (1):6265.

Mavai, D., Lal, S., Singh, K.S.B.A. and Singh, N. 2000. Response of fenugreek. Haryana J Hort. Sci.29 (3/4): 244-46.

Mehta, R.S., Anwer, M.M., Aishwath, O.P. and Meena, R.S. 2012. Growth, yield and quality of fenugreek (Trigonella foenum-graecum L.) as influenced by nitrogen, phosphorus and bio-fertilizers. Indian J. Hort. 69(1): 94-97.

Pareek, S.K., and Gupta, R. 1981. Effect of fertilizer application on seed yield and diosgenin content in fenugreek. Indian J. Agric. Sci. 50(10): 746-49.

Thapa, U., and Maity, T.K. 2004. Influence of nitrogen, phosphorus and number of cutting on seed yield of fenugreek (Trigonella foenum-graecum). Seed Res. 32(1): 33-35.

Tuncturk, R., Celen, A.E. and Tuncturk, M. 2011. The effects of nitrogen and sulphur fertilizers on the yield and quality of fenugreek (Trigonella foenum-graecum L). Turkish J. Field Crops.16 (1): 69-75.

\section{How to cite this article:}

Nilanjana Datta, J.K. Hore and Tapas Sarkar. 2017. Growth and Yield of Fenugreek (Trigonella foenum-graecum L.) As Influenced By Different Levels of NPK under New Alluvial Plains of West Bengal, India. Int.J.Curr.Microbiol.App.Sci. 6(9): 2304-2312. doi: https://doi.org/10.20546/ijcmas.2017.609.282 